\title{
Trânsitos Transatlânticos: os orixás em Portugal
}

\author{
Joana Bahia \\ Doutora em Antropologia \\ Professora na Universidade Estadual do Rio de Janeiro, Brasil \\ joana.bahia@gmail.com
}

Resumo: Este artigo enfoca o candomblé trazido por brasileiros, na década de 1990, para Portugal. Realizei trabalho de campo em terreiros de candomblé das nações efun, jeje, nagô e ketu, em grande maioria concentrados nos arredores de Lisboa e na região Norte do país. Analiso o modo como o candomblé é vivido por seus praticantes no novo contexto, baseando-me na ideia de que a transnacionalização religiosa considera as adaptações das práticas importadas em um contexto bem determinado, seus modos de se "tornarem locais" e a incorporação de novos sistemas de crença.

Palavras-chave: Candomblé em Portugal; Transnacionalização Religiosa; Expansão das Religiões AfroBrasileiras na Europa.

\begin{abstract}
This paper focuses on the Candomble brought to Portugal by Brazilians in the 90's. Field work was carried out in Candomble temples of Efun, Jeje, Nago and Ketu nations, mostly concentrated in the outskirts of Lisbon and in the North of Portugal. I analyse here the way Candomble is experienced by its practitioners in the new context, based on the idea that religious transnationalization takes into account the adaptation of practices imported into a well determined context, their way of "becoming local "and the incorporation of new belief systems.
\end{abstract}

Keywords: Candomble in Portugal; Religious Transnationalization; Expansion of Afro-Brazilian religions in Europe. 


\section{Introdução}

Este artigo enfoca o candomblé trazido para Portugal por brasileiros na década de 1990 e que se expandiu, sendo impossível neste momento contabilizar o número de terreiros existentes no país. Essas observações são resultad de de parte do meu trabalho de campo iniciado em 2010 no Brasil e posteriormente em Portugal e na Alemanha ${ }^{1}$. Em Portugal, trabalhei com terreiros de candomblé das nações efun, jeje, nagô e ketu, em grande maioria nos arredores de Lisboa e concentrados na linha Norte, que compreende a trajetória dos comboios da cidade de Lisboa ao Porto.

Analiso o modo como o candomblé é vivido por seus praticantes no novo contexto, baseando-me na ideia de que a transnacionalização religiosa considera as adaptações das práticas importadas em um contexto bem determinado, seus modos de se "tornarem locais" e a incorporação de novos sistemas de crença (APPADURAI, 2004).

Desde os anos 1960, ocorrem a prática e a expansão das religiões afro-brasileiras (umbanda e candomblé2) na América Latina, especialmente no Uruguai, Paraguai, Venezuela e Argentina. A partir dos anos 1970, elas cruzam o Atlântico e se expandem por Portugal, encontrando-se hoje na Espanha, Bélgica, Itália, França, Alemanha, Áustria, Suíça e estando ainda presentes nos Estados Unidos, no Japão e na Rússia (expansão do Ifá̉).

Essas religiões entraram em Portugal no final dos anos 1970, com a abertura social e política trazida pela lei de liberdade religiosa, sancionada em 2001, instaurada com os ecos da revolução de 25 de abril de 1974. Mãe Virgínia foi uma das primeiras portuguesas que, tendo migrado para o Rio de Janeiro no final dos anos 1940, se iniciou na umbanda ${ }^{4}$ e a trouxe para Portugal (PORDEUS, 2009). Houve uma intensificação da umbanda e do candomblé na última década do século passado, período no qual alguns brasileiros desembarcaram no país e se instalaram como sacerdotes, especialmente a partir da década de 1980, com o aumento dos fluxos de migrantes brasileiros.

Muitos migrantes de países africanos também chegaram a Portugal ainda em fins dos anos 1970, após o período das guerras coloniais, tendo sido seguidos, nos anos 1980 e 1990, pelos brasileiros, chineses, imigrantes do Leste Europeu e indianos (MALHEIROS, 2005). A presença de imigrantes dos países africanos de língua oficial portuguesa (Palop) e do Brasil em Portugal majoritariamente facilitou a perenidade do pensamento colonial. Essa perenidade resultou na reconstrução, dentro de Portugal, da antiga ordem imperial, agora reorganizada com base nas populações imigrantes (MACHADO, 2006).

1 Tive apoio financeiro e institucional, respectivamente, da Fundação Gulbenkian/Portugal e da Faperj/Brasil, o que me possibilitou o financiamento para a realização do trabalho de campo do meu pós-doutorado. No projeto intitulado "A pulsão romântica em transe. Um estudo comparativo da religiosidade afro-brasileira na Alemanha e em Portugal", realizei um mapeamento dos terreiros cariocas e paulistanos que têm vínculo com a Europa. Nesse sentido, a facilidade de iniciar o trabalho de campo no Brasil permitiu maior trânsito pelo candomblé brasileiro em terras portuguesas.

2 O candomblé é a religião dos orixás formada na Bahia, no século XIX, a partir de tradições de povos iorubás, ou nagôs, com influências de costumes trazidos por grupos fons, aqui denominados jejes, e residualmente por grupos africanos minoritários.

3 O Ifá é um sistema de adivinhação iorubá existente na Nigéria, mas que atualmente se encontra em vários países do mundo. O termo Ifá se refere ao orixá Orunmilá, divindade da adivinhação, do destino e da sabedoria.

4 Umbanda é uma religião criada nos anos 1920 na cidade do Rio de Janeiro, sendo considerada, por seu caráter extremamente sincrético, uma religião brasileira por excelência, apropriando-se de elementos do kardecismo e do catolicismo e sofrendo influências indígenas e africanas (PRANDI, 1995). Na umbanda, cultuam-se e incorporam-se entidades, espíritos, e não deuses: qualidades de exus, pombagiras, caboclos, baianos, pretos velhos, boiadeiros, marinheiros e povo do Oriente. Não se incorporam orixás. As entidades da umbanda são arquétipos da sociedade brasileira, ligados a aspectos históricos e culturais do país. 
A imigração mudou Portugal, transformando o país em uma sociedade multiétnica e multicultural em todos os sentidos, inclusive no campo religioso. Atualmente, o país abriga judeus, grupos islâmicos (sunitas e ismaelis), igrejas pentecostais e neopentecostais (incluindo Igreja Universal do Reino de Deus/Iurd, Assembleia de Deus e Maná), igrejas africanas e uma variedade de práticas de migrantes africanos e religiões afro-brasileiras, como umbanda e candomblé ${ }^{5}$. As novas religiões trazidas pelos imigrantes emergem em um momento em que também são protegidas pela lei de liberdade religiosa, como já dito.

Além da dinâmica e da diversidade dos fluxos migratórios, que explicam como se dá a expansão dessas religiões, é preciso ressaltar a importância das práticas mágicas presentes no cotidiano português, o que facilita essa expansão. 1-5, 9-13

A crença em práticas de bruxaria, conforme estudos realizados por Martins (1997), Montenegro (2005) e outros autores ${ }^{6}$ em regiões como Ribatejo, Beiras, Trás-os-Montes e Alentejo, a penetração e o crescimento do espiritismo em Portugal, somados às práticas de um forte catolicismo popular, foram fatores importantes para pensar a aceitação por parte dos portugueses das práticas rituais das religiões afro-brasileiras.

Não obstante a forte repressão do salazarismo à federação espírita e aos centros espíritas, sendo suas práticas religiosas consideradas clandestinas, os espíritas passaram a ser a base de informação para as "bruxas" atuais (MONTENEGRO, 2005: 104). Por meio do transe, das preces, das defumações, esses médiuns continuaram, cada qual de modo independente, curando e libertando os "possuídos", usando sua habilidade em comunicar-se com os mortos para interceder pelos vivos.

Para além das mudanças culturais e sociais vividas no país a partir da abertura política e da chegada de levas de migrantes de várias nacionalidades e religiosidades, como já dito, a cultura portuguesa se aproximou de suas praticas pagãs e populares, há muito tempo adormecidas. Nesse sentido, as práticas sincréticas de ambas as culturas favorecem um largo campo de apropriações, trocas e proximidades.

\section{O mercado religioso português}

Não obstante a crise econômica presente em vários países da Europa, em especial em Portugal, há um mercado religioso variado e em franco desenvolvimento, que não abarca somente terreiros, mas lojas esotéricas e vários modos de atendimento religioso.

Omulu está em Lisboa e, por que não dizer, em todo o território lusitano. Circula pelas cidades e serve de ponte a vários mundos, que compreendem hospitais e postos de atendimento, e continua reavivando sistemas de práticas e crenças populares que relacionam os deuses com os corpos. O orixá considerado "médico" no candomblé (que sabe que tudo que cura também mata) não apenas nos apresenta um Martim Moniz étnico, com suas casas de produtos mágicos e feitiços de origem cultural múltipla (BASTOS, 2001), mas espalha, com suas vestes de palha da costa e búzios, os diversos modos que a religião apresenta de ler o corpo e a saúde.

Houve um crescimento dos terreiros de candomblé de Norte a Sul do país, pois, não obstante o sucesso da umbanda em Portugal, há uma maior legitimação do poder e da força dos terreiros de candomblé, pois chegar a este é atingir um estágio mais elevado (CAPONE, 2009).

Há também uma dificuldade em diferenciar ambos, pois na prática ritual há grande circulação entre os cultos e certa hierarquização - o que se chama de continuum religioso e que também atravessa todo o campo religioso brasileiro. Conforme Capone, “a umbanda é considerada por muitos médiuns uma via de acesso ao candomblé, uma espécie de preparação para se atingir um nível superior. Iniciar-se no candomblé significa um retorno às origens, uma maneira de tornar-se africano" (Idem: 26-27). O mesmo continuum pode ser observado em Portugal, onde, contudo, mesmo se praticando o que é chamado de candomblé, todos levam consigo seus espíritos de exus, pombagiras e caboclos.

5 Sobre o tema, ver Mafra (2002); Pordeus Jr. (2009); Saraiva (2010); e Vilaça (2006).

6 Sobre catolicismo popular, ver Lopes (1995). Ainda temos como bibliografia: Espírito Santo (1984) e Bastos (1985).

EntreRios - Revista do PPGANT -UFPI -Teresina • Vol. 2, n. 2 (2019) 
Entretanto, lembramos que o misturado é sempre o outro; ninguém se diz "misturado", e sim pertencente a uma linhagem tradicional. Os membros dos terreiros em Portugal, sejam de candomblé ou de umbanda, têm uma percepção bem clara da imbricação das práticas rituais. Muitos candomblés no Brasil ditos "tradicionais" e que lutam para se tornar patrimônio cultural afro-brasileiro não realizam rituais de umbanda e suprimem a tradição do caboclo e dos demais espíritos, pois desejam se "reafricanizar". "Quem tiver caboclo que cuide do seu fora do terreiro", disse uma mãe de santo de um dos terreiros mais tradicionais do Rio de Janeiro, o Ilê Omolu Oxum. Terreiros como Casa Branca do Engenho Velho, Gantois e Ilê Axé Opó Afonjá, todos situados na Bahia, embora cultivem seus caboclos, não realizam cerimônias públicas para eles.

Mesmo esse continuum também já tem algumas adaptações, pois, conforme o grande crescimento da umbanda, muitos terreiros de candomblé não apenas cuidam de seus espíritos da umbanda (do pai de santo e de seus filhos), mas também mantêm giras de umbanda como parte dos rituais. Há também praticantes da umbanda, especialmente portugueses, iniciados no candomblé por brasileiros que cuidam de seus orixás com seus pais de santo, mas que preferem abrir terreiros de umbanda.

Essa preferência se dá por terem mais proximidade em termos de conhecimento das práticas católicas e espíritas, que são parte do universo da umbanda, e por conta da maior aceitação por parte dos portugueses em geral. A proximidade da língua cantada nos pontos em português e do gestual próximo às práticas católicas (PORDEUS, 2009), somada às possibilidades de fazer emergir seus próprios espíritos, torna a umbanda bastante atraente.

Em um dos terreiros estudados, na entrada está escrito centro espírita, jogo de cartas e búzios, ao lado do cantinho da Dona Maria Padilha. Isso identifica bem para os portugueses (que em sua maioria têm familiaridade com essas imagens) os serviços religiosos oferecidos. Além disso, no dia a dia do terreiro, são as imagens católicas dos santos que são usadas no congá da umbanda e que ficam expostas, sendo retiradas dias antes da festa de candomblé. Os demais itens, que lembram as caçadas e os animais que se relacionam com um dos orixás do pai de santo (no caso estudado, Oxóssi), permanecem, pois são parte do terreiro. Há também as fotos com os membros da família de santo, as imagens de feitura do pai de santo e os encontros nos rituais de que participou com sua família de santo no Brasil. Todas essas imagens compõem um imaginário que legitima o Brasil como lugar de memória, lugar primevo do candomblé por excelência.

Desse modo, o público é formado tanto por brasileiros que trouxeram a religião para Portugal como por portugueses que a buscam aqui ou foram buscá-la no Brasil. Há também africanos (angolanos, cabo-verdianos e nigerianos) que, ao migrarem para Portugal, buscaram manter sua religiosidade. A adesão de pessoas do Leste Europeu é bem recente.

Há uma variedade de situações que mostram o circuito transnacional de pessoas, objetos e bens simbólicos entre Brasil, Portugal e outros países. Existem pais de santo, brasileiros e portugueses, que mantêm vínculos com suas respectivas famílias de santo, representadas pelos ilês nos quais se iniciaram, e também com os brasileiros (membros de suas famílias) que migraram na década de 1980 e que se encontram em vários países da Europa. Com as migrações nas décadas de 1970 e 1980 de brasileiros e africanos para a Europa, em especial para Portugal, e as sucessivas crises nesse país, os fluxos migratórios tendem a tornar esse xadrez mais complexo, com portugueses indo trabalhar na África, na Venezuela e no Brasil, brasileiros indo para a França, a Alemanha ou mesmo retornando ao Brasil, e também os circuitos dos africanos, configurando uma verdadeira mescla de situações.

Mesmo entre os pais de santo que hoje atuam no mercado religioso português, há vários casos de alguns que não se estabeleceram no país inicialmente como pais de santo, e sim para trabalhar na área de serviços, como qualquer imigrante brasileiro, muitos atuando no comércio e em especial na área de estética. Há então enfermeiros, cuidadores de idosos, jardineiros, cozinheiros, atendentes no comércio e muitos cabeleireiros, que, diante da possibilidade de obter maior prestígio com as práticas mágicas nas quais tinham formação e experiência com seus ilês no Brasil, optaram nas últimas décadas por serem pais de santo. 
Contudo, muitos deles que não desejam viver de santo preferem conciliar suas atividades laborais com as religiosas, não porque não ganhem com suas consultas de búzios e ebós, mas por considerarem um trabalho como profissão, e o outro, não. Há aqueles também que não conseguem conciliar as duas funções e passam a se dedicar somente ao santo, "vivendo de e para o santo".

Há outros brasileiros que já têm ilê no Brasil e vieram a convite de seus filhos para ajudar nos barcos de iaôs (iniciação na religião) e nas grandes festas, mas que passam a ter clientes brasileiros e portugueses. Esses, inicialmente, não pensam em abrir casa em Portugal, mas em eventualmente ter um lugar onde receber a clientela. Muitos o fazem nas casas de seus próprios filhos de santo. Assim, enquanto não abrem seus terreiros, constituem clientela.

Há casos de pais de santo brasileiros que têm ilê no Brasil, que é administrado por algum filho da casa e que mantém um calendário regular de festas, mas que também buscam uma quinta para comprar a fim de abrir seu ilê e permanecer em Portugal. Há também aqueles que têm loja, ilês em Portugal e no Brasil e, quando sobra tempo, ainda atuam em sua profissão original. Há ainda casos dos que tanto têm loja quanto atendem em casa em Portugal, mas que deixaram seus ilês no Brasil sob a administração de algum filho de santo.

No caso dos que têm loja, há um chamado ao esotérico. Como exemplo, a divulgação do comércio axé de produtos esotéricos; contudo, quando se olha o fôlder de divulgação, percebe-se que se trata de candomblé. Foi entrevistado um carioca de Bangu que chegou a Portugal há cerca de 20 anos. Tem 34 anos de santo feito e realiza consultas gratuitas em Aveiro e com marcação em Cantanhede. Seu fôlder mostra uma mãe de santo negra sobre um jogo de búzios. Em seguida, explica o que é o candomblé e que tipo de produtos esotéricos oferece. Logo depois explica sobre os exus, as pombagiras e Iemanjá, elementos mais próximos do entendimento dos portugueses. Depois, uma imagem de Oxumaré marca a ideia de prosperidade, com seus arco-íris de múltiplas cores. $\mathrm{O}$ fôlder se refere à loja dizendo que não se trata apenas de um lugar em que se vendem "amuletos, ervas medicinais, confecção de roupas ritualísticas e demais produtos necessários para seus trabalhos espirituais de umbanda e candomblé", mas também onde se pode obter algum conhecimento sobre "o mistério dos orixás africanos". Assim, a loja é ligada ao terreiro e a seu funcionamento; ou seja, uma coisa leva à outra.

Tal prática é comum e já se encontra em todo o território lusitano, mostrado inicialmente por Guillot (2011), que trata da relação entre o "supermercado religioso" e as diversas religiosidades, qualificadas de New Age (ver TEISENHOFFER, 2007) ${ }^{7}$. A autora afirma que,

[...] no caso das religiões afro-brasileiras, é fato que seus produtos rituais são expostos ao lado de outras práticas ditas esotéricas. De fato, para certos sociólogos da religião os novos movimentos religiosos do Ocidente são caracterizados pelo consumo de diversas tradições, das quais o indivíduo se serve a fim de atender às suas necessidades mais imediatas (GUILLOT, 2011:119).

Muitos dos brasileiros que aderem à religião se iniciaram em Portugal. A conversão se deu no processo migratório. Há também uma parcela daqueles que migraram e que pretendem seguir sua religião em novas terras. Há uma mescla nos candomblés dos brasileiros, que são frequentados em grande parte por portugueses, brasileiros e, em menor escala, por africanos e pessoas do Leste Europeu.

Há grande preferência por alguns tipos de brasileiros e não outros, pois, como toda migração, essa é heterogênea e atravessada por divisões e clivagens, privilegiando, em alguns candomblés, a aderência de portugueses e africanos (no caso de um dos candomblés estudados, muitos nigerianos ${ }^{8}$, que atualmente migram para a Inglaterra).

7 Teisenhoffer (2007) mostra que as origens da filosofia New Age remontam ao século XIX.

8 Tenho o ponto de vista do chefe do terreiro, pois na época em que iniciei o trabalho de campo muitos já haviam migrado para a Inglaterra e não pude contatá-los. 
Os pais de santo brasileiros que preferem não ter brasileiros como filhos de santo argumentam com relação ao baixo nível do fluxo migratório e a questões de gênero, que tornariam seu axé um axé com menos respeito, pelo excesso de homossexuais, que se comportariam como "meninas".

Apesar de as igrejas evangélicas estarem hegemonicamente presentes no contexto português, cabe ressaltar que nem todos os brasileiros em Portugal - mesmo pertencendo aos estratos sociais inferiores - são evangélicos. Parcelas expressivas das últimas levas migratórias de brasileiros para Portugal, como prostitutas, travestis e michês, transitam como membros de suas famílias de santo, participando ativamente da vida ritual. Clientes, donos de casas de prostituição, muitos trazidos pelos brasileiros, solicitam proteção e cuidado com seus negócios. Se, por um lado, muitos pais e mães de santo não gostam de atender essa clientela, pois, além do estigma, há a necessidade de lidar com um ambiente espiritual pesado, como afirmam, por outro, os ganhos são relativamente positivos, pois é um ambiente que demanda muito trabalho (espiritual), por ser "carregado".

Muitos brasileiros são atraídos pela tolerância das religiões afro-brasileiras para com a presença de homossexuais, travestis, transexuais, especialmente em países em que a maioria das igrejas evangélicas presentes condena essas formas de opções sexuais.

Há também, nos vários países europeus, a existência (de maior tempo) de uma legislação favorável às diferentes opções sexuais e que protege os direitos dos homossexuais, além de permitir o casamento de pessoas do mesmo sexo (fato recente no Brasil) ${ }^{9}$. A sexualidade é vivida de modo mais livre e de acordo com uma religião que traz em cena não seres estranhos, mas estrangeiros. Orixás são exteriores à cultura local, e essa descontinuidade em relação à vida social é peculiar no plano dos gêneros ${ }^{10}$.

Outros pais e mães de santo alegam que os brasileiros só procuram a religião visando à obtenção de sucesso profissional e se esquecem de seguir os preceitos, mantendo-se distanciados dos demais filhos de santo. Outros ainda, por se identificarem com a situação migratória de seus filhos, acreditam que a religião seja de fato um suporte emocional e afetivo para eles, podendo se constituir em um caminho para suas vidas. Eles acreditam que "a religião não tem país, língua ou nacionalidade", de modo que não podem negar a entrada de portugueses e muito menos a de brasileiros.

Muitos pais e mães de santo brasileiros não vivem dos jogos de búzios e dos trabalhos que realizam apenas para os clientes locais (na mesma cidade onde estão estabelecidos até cidades mais próximas), havendo também uma circulação por outros países da Europa, o que é facilitado pela proximidade que os meios de transporte propiciam entre as várias cidades europeias. Um dos pais de santo entrevistados tinha acabado de vir dos serviços que havia realizado na cidade de Granada, vindo direto da Espanha para a gira de Exu de outro amigo pai de santo. Ele joga búzios, cartas de tarô e faz ebó. Em um dia, atendia em Coimbra, em outro, em outra localidade da linha Norte. Em outro caso, a mãe de santo entrevistada tinha ido à Suíça para um atendimento maior. Há também outros pais e mães de santo que, quando têm muitos clientes em determinada localidade, ficam nesse local por algum tempo atendendo e, caso abra maior mercado, buscam ter outro lugar já fixo para atendimento.

Muitos irmãos, filhos e mães e pais de santo se encontram vindos de países como França, Espanha e de outras partes de Portugal e da Europa nas festas de orixás e nas giras das almas, a fim de confraternizar, contar casos, lembrar as histórias de família, piadas, jogos e desavenças. A fofoca é um modo de regular as práticas e o jogo de legitimidade entre portugueses e brasileiros. Muitos lembram suas próprias migrações e os modos como construíram seus axés.

Muitos tentam seguir o calendário do Brasil, mas não há total regularidade. Outros juntam os aniversários de feitura de santo com os de seus filhos.

9 Essa tolerância também atrai parcelas de outros grupos, pois a opção sexual muitas vezes se afirma no momento de escolha dessa religião, e muitas mudanças de vida e de atitude acompanham esse momento.

10 Parcela da imigração brasileira pouco estudada nos grandes círculos acadêmicos, que se detêm nos meandros do gênero e/ ou da estética e não se referem ao modo como esses segmentos absolutamente marginalizados circulam no candomblé em Portugal. Esses segmentos não são alvo dos estudos migratórios (PISCITELLI, ASSIS \& OLIVAR, 2011: 7), menos ainda sua circulação em espaços religiosos. 
Mesmo com a característica disputa entre os pais e as mães de santo, muitos são padrinhos e participam dos rituais de feitura dos filhos e filhas de santos uns dos outros, mesmo quando ainda não possuem terreiro, e sim cerimônias improvisadas em apartamentos. Esse é o caso de um pai de santo, que, quando ainda morava em Lisboa, convidou outro pai de santo para ver seu Ogum em um ritual improvisado em seu apartamento nessa cidade. Foi a primeira vez que viu seu santo e, quando o filho deste foi iniciado em Logunedé, ele convidou seu amigo para a saída de $i a \hat{o}$.

Não obstante a importância das mães e/ou dos pais de santo de origem portuguesa que trouxeram do Brasil os novos modos de ler a África, com olhos dos brasileiros e alma lusitana (PORDEUS, 2009), há a presença de pais e mães de santo brasileiros em solo português. Muitos brasileiros e portugueses atualmente se organizam em federações e ONGs, de modo a não só demarcar presença em solo português, mas na disputa pela legitimidade de quem pratica o verdadeiro candomblé, o mais africano. Ou quem sabe o mais brasileiro? Ou ainda um candomblé em português de Portugal?

Nesse jogo acusatório, há o fato de que se, por um lado, o Brasil preservou o candomblé e se fez responsável pela formação dos terreiros portugueses, "por si mesmos considerados mais tradicionais", muitos acusam o excessivo sincretismo de ser uma marca brasileira, o que torna o candomblé mais imperfeito, de modo que os portugueses seriam mais aptos a lhe conferir mais pureza, pois sob a ótica colonial teriam tido contato com África.

Muitos portugueses que se iniciaram na religião evocam elementos reais ou imaginários, constituídos de uma origem afrodescendente, que lhes permitem explicar uma predisposição quase natural às práticas de religiões consideradas não mais afro-brasileiras, mas africanas. Conforme Halloy (2001-2002), temos a justificativa de um pai de santo belga que legitima sua escolha religiosa relacionada com o fato de que o Congo era belga, logo africano.

Por um lado, acionam o Brasil como lugar do candomblé primeiro, o que lhes confere uma legitimidade, especialmente diante de outros axés ou de brasileiros que conhecem suas famílias de santo. Muitos evocam o Brasil como um lugar "natural do sincretismo e da mistura de povos" e o comparam a suas próprias origens étnicas, reconfigurando sua história com o candomblé. Como exemplo, o depoimento de um filho de santo romeno: "Terra de misturas, a bruxaria da Romênia é muito pesada. Junta os ciganos, bruxaria russa, é como se fosse o Brasil com nações de centenas de anos".

Por outro lado, em outras circunstâncias, desnacionalizam a religião como sendo o candomblé da Bahia, reconstruindo a ideia de África como parte de uma história pessoal que, no caso dos portugueses, se confunde com uma herança pós-colonial. Nesse caso, a África é repensada como parte de sua própria nação. $\mathrm{Ou}$, ainda, dependendo do interlocutor e da situação, aciona-se o epíteto "religião dos orixás", que denota não ter nação, cor ou lugar. Isso não somente lhe retira a ideia de pertencimento a uma raiz cultural africana, mas também permite que a religião tenha o mesmo estatuto transnacional de um cristianismo.

Os próprios portugueses reclamam da dificuldade que seus conterrâneos têm em relação ao respeito à ideia de tempo, que determina o quanto a pessoa tem autoridade na religião. Muitos chegam acreditando que já podem ser pais e mães de santo (cargos que são atribuídos pelos orixás no jogo de búzios), não têm a "humildade dos brasileiros" e não admitem começar na religião como "simples abiãs" (iniciantes). Muitos admiram a presença dos africanos, que, mesmo em pequeno número, têm enorme respeito e compreensão pela religião e seus preceitos; esse é o caso de um terreiro em que havia vários nigerianos. Em um dos terreiros pesquisados, a mãe de santo tinha extrema dificuldade em lidar com os brasileiros, parte majoritária de seu terreiro, pois não negava perceber que muitos vinham de baixos estratos sociais da imigração e, portanto, tinham hábitos "pouco afeitos à educação europeia" (e a classe média branca, que constitui parcela dos portugueses que frequentam os terreiros).

Por outro lado, os brasileiros acusam os pais de santo portugueses de deturpar a religião em função das adaptações dos rituais, de modo que muitos, por ocasião das iniciações, mandam os filhos de santo para seus axés no Brasil, pois acreditam que esse país reúne os conhecimentos e a natureza (rios, cachoeiras etc.) propícios para os ritos, não precisando de permissão para toque de atabaque, festas e sacrifícios. 
Os portugueses são acusados de ter uma visão bastante equivocada da religião, e "muitos já chegam como esotéricos", mas sem nenhum conhecimento da religião que procuram ou a manifestação da presença do orixá em suas vidas. Muitos são atendidos como clientes, mas muitos também são postos para fora do terreiro no que se refere ao processo iniciático.

Não obstante a umbanda e o candomblé constituírem um marco institucional, que para muitos significa ser parte de um grupo, de uma comunidade, o que tornaria a religião mais legítima na sociedade, mais ampla, ao contrário dos bruxos e videntes, que atuam isoladamente (GUILLOT, 2011: 118), isso não significa que não haja dificuldade de entendimento do que seja um pai de santo ou do que seja de fato um terreiro de candomblé. Muitos apontam a dificuldade de explicar os orixás diante da total abstração e da pouca materialidade de seus assentamentos. "Como explicar que aquele monte de ferro velho é Ogum? Como fazer entender que Iemanjá não é aquela figura cândida que carrega pérolas nas mãos? Como explicar ao mesmo tempo que tudo o que nos cerca é orixá?", reclama um pai de santo.

Muitos brasileiros se veem mal compreendidos diante da excessiva influência da bruxaria e do espiritismo entre os portugueses, que "tendem a confundir pai de santo com vidente", além de desconhecerem as regras de bom convívio entre os pais e as mães de santo.

Os portugueses de alguns axés "ditos mais tradicionais" começam por formar seus intelectuais da casa a fim de demarcar sua presença de africanidade e dar maior legitimidade aos que entendem o candomblé no cenário religioso. Contudo, é um candomblé escrito com o português de Portugal. Como exemplo, a publicação de artigos e livros sobre o tema de um de seus intelectuais (ver FERREIRA DIAS, 2012) e também a recriação do ritual das águas de Oxalá "tal qual se faz na África" pelo mesmo terreiro. As disputas quase silenciosas são visíveis, e mesmo as famílias e casas de candomblé presentes no Brasil mantêm vivas suas disputas em solo português. Migrar, nesse sentido, é o migrar dos orixás para dar continuidade ao axé em novas terras. Então, há casas dos filhos das mães de santo da Baixada Fluminense carioca, periferia baiana e demais axés concorrendo entre si ao papel de pioneiros do axé em águas internacionais. No processo de transnacionalização das religiões afro-brasileiras, especialmente no caso do candomblé, os axés circulam em grande parte entre Rio de Janeiro, Bahia e São Paulo, mostrando que muito pai de santo português pode falar um bom sotaque baiano.

Pero Vaz de Caminha que me desculpe, mas agora a viagem é ao contrário, pois todas as religiões que em Portugal se implantaram florescem.

\section{A etnografia dos espíritos}

A presença das entidades era apenas real para os religiosos, sendo irreal para os pesquisadores. Isso mostra que, não obstante os espíritos serem parte da pessoa, esses não eram parte da realidade descrita. Mas, ao nos aproximarmos dos espíritos, também nos aproximamos das pessoas. De que modo os espíritos agem? Qual o poder que lhes é designado? Em que circunstâncias interferem nas relações (sexuais, familiares e conjugais) de seus médiuns?

Com base no trabalho de Wafer (1991), é possível observar que os relatos etnográficos dos relacionamentos (mulheres, espíritos, filhos, amantes) permitem nos aproximar da perspectiva dessas pessoas. Conforme Boyer mostra em seu trabalho:

[...] os espíritos estão ali, em torno dos seres humanos e que intervêm a qualquer momento nas suas vidas. A questão principal é então como interpretar os seus conselhos e suas ordens, como viver com eles sem que o curso da existência de seus efeitos não seja modificado de forma irrefletida (BOYER, 1993: 408).

Hayes (2011) propõe que se integre a realidade descrita pelo pesquisador à que é concebida pelos religiosos, envolvendo as relações das entidades com as quais a pessoa trabalha.

Baseando-me nos trabalhos de Hayes, Boyer e Wafer, realizo o que chamo provisoriamente de "etnografia dos espíritos", isto é, tomo como ponto de observação os efeitos e os produtos da possessão para seus praticantes e também busco entender como se dão as práticas rituais, a fim de identificar apropriações e sincretismos. 
Segui, então, o espírito do caboclo Pena Dourada, a fim de perceber as circularidades, adaptações e releituras de algumas práticas religiosas em ambos os países, Brasil e Portugal. É preciso lembrar que os espíritos da umbanda falam um português arcaico, especialmente os caboclos, espíritos dos índios brasileiros, considerados os primeiros habitantes do Brasil, que falavam guarani antes da chegada dos portugueses.

Portugal é chamado pelo caboclo de Putamagal, uma alusão à ideia de que ele veio antes dos putamagaleses, em uma fina ironia de quem migrou juntamente com seu cavalo (aquele que o incorpora), denotando a visão de um índio brasileiro em terras lusitanas. Em sua prática ritual, carrega a bandeira do Brasil nas costas, com o peso de quem carrega a nação e a identidade.

Os caboclos são os donos da terra, primeiros habitantes da floresta e das matas brasileiras (SANTOS, 1995); vieram de Aruanda, localizada no Congo, tendo migrado para Angola, uma nova Aruanda, quando este foi destruído. Habitantes do Brasil, juntamente com os pretos velhos, plantaram o axé, e somente depois chegaram os putamagaleses.

Não obstante a ideia inicial de um sentimento nacionalista utópico, vemos uma infinidade de caboclos e uma possibilidade, por que não dizer, de incorporar elementos estrangeiros - de Aruanda, Congo, no Brasil ou em Putamagal.

Ao contrário dos orixás, que são em número fixo, os caboclos são infinitos. Não obstante a tônica nacionalista a que primeiro eles são associados, há um sentido de "irmandade universal", em que espíritos não indígenas e não brasileiros podem ser incorporados. Conforme Wafer, "talvez o link etimológico entre o caboclo e a mistura de raças torne a tradição do caboclo um veículo simbólico para a incorporação no candomblé de elementos estrangeiros” (WAFER, 1991: $55)$.

Pordeus (2009) mostra a existência de espíritos portugueses, como o famoso Marinheiro Agostinho. Em alguns casos, pretos velhos e caboclos podem ser de entidades portuguesas "escondidas", isto é, passam por brasileiras para ser aceitas e inseridas no culto. Incorporar um espírito brasileiro confere certa legitimidade e autenticidade à prática religiosa, pois muitos veem com descrença (especialmente alguns dos pais de santo brasileiros) o fato de se ter incorporado outra "nacionalidade" ${ }^{\prime 11}$.

Carinhosamente chamada de samba pelo caboclo Pena Dourada, Ana (de origem portuguesa) - cambona, ou aquela que não incorpora e ajuda os espíritos na comunicação com as pessoas - trouxe sua fé em São Cipriano para o terreiro, fruto de sua vivência espiritual no interior de Portugal no tempo em que, quando retornara da África, havia tomado uma bruxa como mãe espiritual. Deste então, São Cipriano viaja muito.

Um dos aspectos de implantação das religiões afro-brasileiras em Portugal está na reordenação das experiências da religiosidade popular portuguesa que elas operam. Não obstante o decréscimo do catolicismo no país ${ }^{12}$, isso não significa, na prática, que não haja reorganização do que seja ser católico, e nesse sentido as religiões afro-brasileiras contribuem para essa tarefa ${ }^{13}$.

11 Coincidentemente ou não, em meu trabalho de campo encontrei vários marinheiros portugueses. Não sei se de fato a ótica colonial prevalece e também povoa o mundo dos espíritos.

12 Conforme relatório produzido pelo sociólogo Alfredo Teixeira, há um decréscimo dos católicos e um crescimento dos chamados não crentes. Observa-se uma diversidade religiosa maior nos arredores de Lisboa e Vale do Tejo. Temos ainda no relatório uma concentração de católicos na região Norte, com 43,6\% em relação ao total da mostra. O que pude averiguar em meu trabalho de campo é que é justamente na linha Norte que temos um crescimento grande das religiões afro-brasileiras, especialmente nas áreas tradicionalmente católicas, como Aveiros, Braga e Porto (TEIXEIRA, 29012).

13 Cabe lembrar que o estudo da Universidade Católica Portuguesa (referido anteriormente) não contempla as religiões afro-brasileiras e que no Brasil comumente as pessoas que são filiadas a essas religiões se identificam nos censos como sendo católicas. Há uma campanha lançada em 2010, na cidade do Rio de Janeiro, promovida pela Mãe Beata (Quem é de axé diz que é!), que solicita aos adeptos da religião que se identifiquem no censo, como modo de lhe dar visibilidade diante do crescimento das igrejas neopentecostais. 
São Cipriano foi adotado pelo caboclo Pena Dourada nas giras das almas, tornando-se parte delas. Assim, quando o caboclo volta para o Brasil, ele o traz para as sessões na Baixada Fluminense, cidade do Rio de Janeiro. Famoso em terras tanto lusitanas quanto brasileiras, no período de meu trabalho de campo, São Cipriano fez muitas viagens entre Rio de Janeiro e Lisboa.

No Brasil, São Cipriano foi batizado com sangue de sacrifício animal e circulava sujo de sangue no colo dos presentes ao rito; quanto mais tempo o adepto permanecesse conversando com ele, mais poder era atribuído a seus pedidos. O sangue e o tempo significavam uma potência que caracterizava seu aspecto de bruxo africano, ou negro, por ser conhecedor da feitiçaria em si mesma, seja boa ou má.

Não se ameniza a feitiçaria pela condição de conversão ao catolicismo, pois muitos feitiços são parte mesmo da vida católica. Muitos feitiços podem ser feitos dentro da Igreja. Mesmo aqueles pais e mães de santos mais reticentes em se aproximar da fé católica, especialmente os mais tradicionais, sabem algum feitiço.

Atualmente, há dois São Ciprianos; o lisboeta perdeu uma das mãos, mas ainda acompanha os pedidos de vários praticantes, indo às vezes morar em outra freguesia que não a do terreiro. Contudo, ele sempre volta.

Na versão mais católica e umbandista de uma mãe de santo portuguesa, há um São Cipriano mais convertido à fé católica. Quando fala de São Cipriano, ela afirma ser bastante popular em Portugal, mas que muita gente o considera bruxo. Contudo, quando o representam desse modo, ela logo justifica "que ele só fazia o bem, pois havia se convertido".

Não obstante não haver regularidade no calendário de vários terreiros observados, ela existe em alguns rituais que mostram não apenas adaptações, mas sincretismos e novas apropriações. Grande parte das oferendas a Iemanjá ${ }^{14}$ e Oxum é realizada nos meses de dezembro e fevereiro, dois meses também próximos ao calendário dos terreiros cariocas. No Rio de Janeiro, há a festa de Iemanjá promovida pelo Mercadão de Madureira, grande mercado carioca dedicado aos produtos necessários aos rituais dessas religiões.

Mas há também alguma regularidade nas festas de Ogum (bastante presente em vários terreiros, juntamente com as festas de São Jorge no Brasil) e nas giras das almas, e em especial no dia 13 de maio, em que se homenageiam almas e pretos velhos, seguindo em geral as festas em que participavam em seus ipês ou nos de seus pais e filhos de santo.

Muitos fazem como prato principal a feijoada, considerado representativo do que é a nação brasileira como constituída por uma nação de negros escravos. E muitos, aconselhados por seus espíritos, também fazem bacalhau, pois, conforme relata um pai de santo entrevistado (aconselhado pelo espírito do caboclo Pena Dourada), "tendo os espíritos (eguns) migrados para outro continente, temos também que homenagear os espíritos dos outros". Temos o que pode ser considerado uma releitura étnica, ressaltando elementos identitários relacionados a cultura brasileira.

Conforme afirmei anteriormente, para além da presença de brasileiros, portugueses, africanos, existem imigrantes do Leste Europeu. Poucos, mas significativos.

14 Constato o enorme sucesso que Iemanjá faz na crença dos portugueses ao refletir sobre o crescimento do mercado religioso: além de ela compor parte da vitrine de boa parte das lojas esotéricas, está presente entre os santos de qualquer comércio mais católico, sendo ainda fabricada e vendida na cidade de Fátima. Passeando com o antropólogo Ismael Pordeus por um dos comércios nos arredores de Anjos, em Lisboa, ao lado de orações a Santo Antônio, Fátima e demais santos populares no panteão português, vi muitas orações a Iemanjá, fato novo, pois nunca observei tal fenômeno de apropriação religiosa ocorrer no Brasil. Em uma das lojas mais conhecidas de Lisboa (e responsável pelo envio de material religioso para toda a Europa), não obstante seu dono afirmar que "só quer vender", sempre se percebem lógicas mágicas associadas a trocas comerciais. Tudo pode ser vendido na loja, menos a Iemanjá da vitrine, pois se trata de um assentamento. Não obstante a loja se chamar Armazém de Xangô, quem manda no comércio desse "cético comerciante" alemão casado com uma mãe de santo brasileira é Iemanjá. As mesmas relações podem ser observadas no famoso Mercadão de Madureira, centro comercial que constrói sua identidade relacionando-a com o lugar de fornecedor de matéria-prima necessária aos principais ritos das religiões afro-brasileiras. É desse mercado que sai todos os anos uma procissão de Iemanjá no mês de dezembro, antes dos festejos do Ano-Novo. 
Entrevistei um filho de santo romeno, de 46 anos, e que é cozinheiro de profissão. Ele foi iniciado com um pai de santo português e por vários motivos mudou para uma mãe de santo brasileira. Além dos problemas espirituais por erros cometidos pelo referido pai de santo (acusação bastante comum no mercado religioso), outro motivo notório foi o descuido na observância dos rituais, em especial aqueles que se referem ao preparo da comida, ao abate dos animais e ao uso dos alimentos e louças específicos para cada orixá. Por ser cozinheiro, detalhes sobre cortes de alimentos, sacrifícios dos animais, modos de cozinhar e de ofertar para os orixás não lhe passavam despercebidos. Ele tem cargo, ou seja, deverá ser pai de santo. Ainda não sabe jogar búzios, mas joga cartas húngaras. Assim, apropria-se das cartas e da religião, aproximando-se de sua cultura de origem:

\begin{abstract}
São cartas bonitas. É ensinamento, uma senhora metade húngara e romena, muito boa, e eu via sempre os jogos dela. Eu observava. Fui sempre uma pessoa curiosa, ninguém me ensinou como se deita. Eu aprendi sem ser ensinado. Ela deitava as cartas, e eu estava ao lado e prestava atenção. Os húngaros têm as próprias cartas deles. Tem mistura de cigano e do povo húngaro, povo de Átila, do grande fundador da Hungria. Vieram da Mongólia estepe, tribos que se instalaram no campo panônico, lugar entre Romênia e o povo germânico. Eles criaram eles próprios a magia húngara, que é muito forte. Tem junção da magia húngara, cigana e russa. Energia bastante forte. Cidade era mais húngara que romena. Aprendi ao olhar as cartas e depois comecei a praticar, com 16 anos. Eu não viro, mas tenho um cigano que se chama Paquito. Tem que cuidar do povo cigano, originário da Romênia e da Hungria. Marias Padilhas, pombagiras [...]
\end{abstract}

Mesmo em menor escala, a presença dessas pessoas no candomblé de brasileiros revela não apenas um território lusitano pagão, mas uma Europa pagã, em que seus vários migrantes agregam suas crenças à abertura que encontram nas religiões afro-brasileiras. Eles mesclam as práticas da religião às cartas húngaras, à leitura da borra de café e se reconectam com suas tradições populares, evocando o passado cigano presente na história das migrações da população de suas nações. Não apenas leem cartas, mas também agradam a seus ciganos.

Muitos iniciados trazem acumuladas diferentes práticas, como o tarô de Marselha, as runas, ou também se iniciam na santeria cubana (mesclando-a com práticas New Age, como o Reiki), e outros praticam a religião celta, wicca ${ }^{15}$, evocando os mestres da grande fraternidade branca. O uso de ervas e a concepção de natureza da wicca se aproximam em muito da concepção dos orixás - como quando se associa o orixá Nanã à própria ideia de terra, ao domínio do barro para construir o mundo. Muitas associações entre essas religiões mostram uma espécie de ancestralidade comum, que primeiro pertenceu à África, sendo legitimada pelo Brasil, que "guardou os feitiços", e depois evocada como um saber esotérico na Europa.

\title{
Referências Bibliográficas
}

APPADURAI, A.. "Dimensões culturais da globalização", in A modernidade sem peias, Lisboa, Teorema, 2004.

BASTOS, C. "Bruxas e bruxos no Nordeste Algarvio". Porto: Trab. Antropologia e Etnologia, 1985 2-4

V,p.303-324.

Omulu em Lisboa: Etnografias para uma teoria da globalização, Lisboa, Etnográfica, 2001,

BOYER, Véronique, Femmes et cultes de possession au Brésil. Les compagnons invisibles, Paris, L'Harmattan, 1993.

15 Religião fundada na primeira metade do século XX, inclui diversas crenças xamânicas, celtas, greco-romanas ou mesmo nórdicas, e seus adeptos praticam o culto à natureza. 
CAPONE, Stefania, A busca da África no candomblé: Tradição e poder no Brasil. Rio de Janeiro: Contracapa/Pallas, 2009.

FERREIRA DIAS, João. Candomblé em português. História. Organização. Teologia Asèwétà | Lisboa: Comunidade Portuguesa do Candomblé Yorùbá, 2012.

ESPÍRITOSANTO, Moisés. A religião popular portuguesa. Lisboa: A Regra do Jogo Edições, 1984.

GUILLOT, Maïa, "Bruxaria, catholicisme populaire et religions afro-brésiliennes: reflexions sur l'adaptation du candomblé et de l'umbanda au champ religieux portugais". In Stefania CAPONE e Kali ARGYRIADIS (eds.), La religion des orisha. Un champ social transnational en pleine recomposition, Paris, Hermann, 2011, p. 99-135.

HALLOY, Arnaud, "Un candomblé en Belgique. Traces ethnographiques d'une tentative d'installation et ses difficulties". In: Psychopathie Africaine, Dakar, 2001-2002, vol. XXXI, n. 1, p. 93 125.

HAYES, Kelly Black, Holy harlots. Feminity, sexuality and black magic in Brazil, Berkeley/Los Angeles/London, University of California Press, 2011.

LOPES, A. Religião Popularno Ribatejo. Santarém: Assembleia Distrital de Santarém, 1995.

PISCITELLI, A., G. de O. Assis, e J. M. N. OLIVAR. 2011. "Introdução: transitando além de fronteiras". In: Gênero, Sexo, Afetos e Dinheiro: Mobilidades Transnacionais Envolvendo o Brasil. Campinas: Unicamp/Pagu, Coleção Encontros, 5-30.

PORDEUS Jr., Ismael. Portugal em transe. Transnacionalização das religiões afro-brasileiras: Conversão e performances, Portugal, Instituto de Ciências Sociais da Universidade de Lisboa, Coleção Antropologia Breve, 2009.

PRANDI, Reginaldo. As religiões negras no Brasil. Por uma sociologia dos cultos afro brasileiros. Revista USP ,São Paulo(28 ):64-83, dezembro/fevereiro 95 / 96.

MACHADO, Igor J. R.. Imigração em Portugal. Estudos Avançados, São Paulo, USP, 2006a, n. 57.

MAFRA, C. Na Posse da Palavra, Religião, Conversão e Liberdade Pessoal em dois contextos nacionais. Lisboa, Imprensa de CiênciasSociais, 2002.

MALHEIROS, Jorge."Jogos de relações internacionais: repensar a posição de Portugal no arquipélago migratório global”. In: Antonio BARRETO (ed.), Globalizações e migrações, Lisboa, Instituto de Ciências Sociais, 2005, p. 251-272.

MARTINS, José Garrucho. As Bruxas e o Transe: dos Nomes às Práticas. Vila Nova de Gaia, Estratégias Criativas, 1997.

MONTENEGRO, Miguel. Les bruxos: Des thérapeutes traditionnels et leur clientèle au Portugal, Paris, L'Harmattan, 2005.

SANTOS, Jocélio Teles, O dono da terra. O caboclo nos candomblés da Bahia, Salvador, Sarah Letras, 1995.

SARAIVA, Clara . "Afro-Brazilian religions in Portugal: bruxos, priests and pais de santo". Etnográfica, Lisboa, v. 14, p. 265-288, 2010. 
TEIXEIRA, Alfredo. Catolicismo e "outras identidades religiosas em Portugal": coordenador do estudo propõe interpretação dos resultados. Secretaria Nacional da Pastoral da Cultura, 2012. Disponível e $\mathrm{m}$ <http://www.snpcultura.org/catolicismo e outras identidades religiosas em portugal int erpreta \%C3\% A7\%C3\% A3o.html>.Consultado em 13 de abril de 2020.

TEISENHOFER, Viola. Umbanda, New Age et psychothérapie: aspects de l'implantation de l'umbanda à Paris. Atéliers d' anthropologie, Nanterre, v. 31, 2007.

VILAÇA, Helena. Da Torre de Babel às Terras Prometidas Pluralismo Religioso em Portugal, Porto: Edições afrontamento, 2006.

WAFER, Jim, The taste of blood. Spirit possession in Brazilian candomblé, Philadelphia, University of Pennsylvania Press, 1991. 